\title{
PERADABAN PSIKOLOGI PENDIDIKAN
}

\author{
Ismail Sangkala \\ Universitas Muhammadiyah Makassar \\ ismail@unismuh.ac.id
}

Pada saat sekarang ini, kita berada pada ambang revolusi penelitian tentang otak yang telah mengarah kepada arah perubahan baru. Baik dalam hal metode penilaian, strategi mengajar, lingkungan kelas dan penggunaan teknologi. Dalam bagian ini, yang menjadi konsep-konsep utama antara lain; latar belakang dan teori yang berkesinambungan dalam hal penelitian tentang otak, hal yang menjadi ketetapan dan petunjuk penelitian pada saat ini, instrument untuk mempelajari tentang otak, dan bagaimanakah memahami penelitian baru tentang otak.

Pola pikir atau paradigma dalam hal pendidikan, mengalami perubahan dengan cara berkesinambungan atau setiap dekade sampai pada saat sekarang ini. Pada awalnya, muncul pemikiran bahwa "jika kita menginginkan sesuatu, seharusnya kita berusaha untuk mencapainya. Ibaratnya pembantu dengan seorang majikan, pembantu membutuhkan materi dari majikan sehingga dia mematuhi dan mengabdi kepada majikannya. Sehingga jika seseorang membutuhkan ilmu, maka kita harus mencari orang yang lebih pandai dari kita untuk belajar kepadanya. Tetapi pada tahun 1800 atau pada abad ke-20, paradigma diatas dirubah atau dikembangkan dengan memunculkan model 
pendidikan yang baru, dengan memperadakan sistem standarisasi dengan adanya kurikulum pendidikan yang baku. Dimana hal itu, lebih dikenal dengan sebutan "factory model". Sebutan ini digambarkan dari aspek sosiologi, bisnis dan agama. Hal ini menekankan kegunaan pada kemampuan seperti kepatuhan, ketertiban, persatuan dan kehormatan terhadap kewibawaan.

Pada tahun 1959 dan 1960, muncul kembali pola pikir atau paradigma baru tentang teori tingkah laku. Hal ini diajarkan oleh psikologis John Watson dan B.F Skinner. Teori tingkah laku mereka seperti ini: "Kita boleh tidak tahu yang masuk ke otak kita, tetapi pastinya kita bisa lihat apa yang terjadi diluar sana. Ukurlah tingkah laku itu dan belajar merubahnya dengan penguatan tingkah laku juga. Jika kita suka, maka hargailah, jika tidak maka hukumlah".

Saat ini, sebuah paradigma baru muncul yang merubah paradigma lama melalui teknologi. Perubahan itu meliputi alur berpikir kita, kehidupan, dan belajar. Pada tahun 1970, 1980, 1990. Terciptalah Magnetic Resonance Imaging $\underline{\text { (MRI) sebagai "mesin peninjau/pengamat otak" dan Positron Emission }}$ Tormography (PET) memberi kita jalan baru untuk mengerti dan melihat isi otak. Untuk pertama kali dalam sejarah, kita bisa menganalisa otak selama seseorang masih hidup. Sebuah turunan baru yang dikembangkan yaitu "neuroscience" sebuah cabang ilmu luar biasa yang membahas tentang otak.

Pada tahun 1969, 500 pakar neuroscience terdaftar di Lembaga Internasional Neuroscience. Saat ini, beranggotakan lebih dari 30.000. Sebuah keuntungan dari 
pengembangan wawasan tentang otak dan aspek belajar. Schizophrenia dan Tourette's syndrome dapat disembuhkan dengan pengobatan. Sekarang ini, dikembangkan sebuah pil memori untuk membantu siswa dalam mengingat apa yang mereka baca.

\section{Bagaimanakah Kita Belajar Tentang Otak?}

Kita sedang belajar tentang otak pada sesuatu yang belum terjadi. Jeri Janowsky, mengatakan bahwa apa saja yang anda pelajari dua tahun lalu itu adalah informasi yang telah lama. Sekarang ini teknologi telah dapat menjelaskan atau menerangi misteri terselubung dari otak.

Dengan mempelajari revolusi penelitian ini, kita sebagai penikmat atau pelaku pendidikan merasa terbantu untuk lebih mengenal sistem dan proses kerja otak kita. Kita telah paham bahwa betapa banyak fungsi dan hal-hal yang misterius di dalam otak kita. Bagian ini telah memperkenalkan revolusi-revolusi teori dan instrument tentang otak, sehingga kita tidak merasa tabu lagi akan hal itu ketika kita melihat dan mengaplikasikannya. Perubahan disetiap dekade dijelaskan secara struktural, sehingga memberikan referensi ilmu bagi akademisi dan praktisi psikologi.

Materi ini pula telah membuka gambaran bagi pembaca tentang pentingnya kemajuan teknologi untuk mengembangkan bidang keilmuwan khususnya dalam psikologi. Sehingga dapat ditarik benang merah bahwa ilmu 
dan teori harus selalu dikembangkan seiring perkembangan zaman. Telah dilihat sebelumnya tentang revolusi-revolusi ilmu pengetahuan, yang berkembang disetiap tahun atau dekade. Hal ini menjadi cerminan kemampuan manusia memunculkan dan menjalankan penelitian mereka. Sebagaimana dikatakan bahwa "Tidak ada teori yang salah, tetapi bagaimana kamu melihat teori itu bermanfaat bagi kamu"(Jeri Janowsky), pernyataan ini dimaksudkan untuk tetap bereksperimen, jangan takut menciptakan teori dan metode baru karena kesemuanya itu kembali pada pemanfaatannya.

Sebagai akhir dari artikel ini, penulis menyimpulkan tiga hal yang harus dilakukan oleh seorang pendidik, antara lain:

1. Menjadi "Consumer Literate" dalam bidang penelitian otak, belajar dari sumbersumber penelitian dengan menyimpulkan, manakah yang dapat dipercaya atau tidak.

2. Membutuhkan penelitian tindakan bukan hanya mengajarkan teori. Mulailah disekitar kita dari yang terkecil hingga menghasilkan produk.

3. Menyebarkan informasi-infomasi ini kepada masyarakat umum. Dengan cara melalui siswa hingga tersebar kebeberapa kalangan baik keluarga maupun lingkungan sekitar.

\section{Referensi}

Jensen, Eric (1998)." Teaching with the Brain in Mind ": Association for Supervision and Curriculum Development: St. Alexandria USA. 